\title{
External networks and institutional idiosyncrasies: \\ The Common Security and Defence Policy and UNSCR 1325 on women, peace and security
}

Jutta Joachim, Andrea Schneiker, Anne Jenichen

\begin{abstract}
In 2008, the Council of the European Union adopted a 'Comprehensive Approach' that outlines a strategy for securing gender mainstreaming; two years later, the Council introduced a set of indicators to assess its implementation. The EU was responding to the United Nations Security Council's call for regional institutions to assist in implementing Security Council Resolution (UNSCR) 1325, adopted on 31 October 2000, concerning women, peace and security. This resolution sought to meet the 'urgent need to mainstream a gender perspective into peacekeeping operations'. Considering that prior exposure to gender issues, resources and well-established relations with civil society and gender advocates are lacking, adoption of both the Comprehensive Approach and the indicators, as well as the structures and procedures established since then as part of the EU's Common Security and Defence Policy, requires some explanation. This article draws on feminist institutionalist approaches to argue that the impetus for change came from individuals and groups within the EU who were involved in external networks, both above and below the supranational level, who seized on institutional idiosyncrasies that, in contrast, also shaped implementation of UNSCR 1325 in important ways.
\end{abstract}

\section{Introduction}

In 2008, the Council of the European Union (EU) adopted a 'Comprehensive Approach' that outlines a strategy for securing gender mainstreaming (Council 2008a, 2008b); two years later, the Council introduced a set of indicators to assess its implementation (Council 2010). These measures were in response to the United Nations Security Council's call for regional institutions to assist in implementing its resolution 1325 concerning 'women, peace and security' (UNSCR 1325), which was adopted on 31 October 2000, and to meet the 'urgent need to mainstream a gender perspective into peacekeeping operations' (UNSC 2000, 2). However, the structures and procedures subsequently established by the EU as part of its Common Security and Defence Policy (CSDP) need to be understood in light of certain 
institutional hurdles that have impeded the integration of gender into the CSDP.

Overall, 'gender mainstreaming is a demanding strategy, which requires policy-makers to adopt new perspectives, acquire new expertise and change their established operating procedures' (Pollack and Hafner-Burton 2000, 450; see also Weiner and MacRae 2014, 6). As noted in the European Commission's 1996 communication 'Incorporating equal opportunities for women and men into all community policies and activities' (when this strategy was first introduced into the EU), gender mainstreaming requires a Comprehensive Approach that involves 'mobilizing all general policies and measures specifically for the purpose of achieving equality by actively and openly taking into account ... their possible effects on the respective situations of men and women (gender perspective)' (EC 1996, 2).

Gender mainstreaming affords 'a new modus operandi for its realization' (Weiner and MacRae 2014, 5), because it tries not only 'to change or tackle structural inequalities, [but] aims at changing institutionalized inequalities' (Paantjens 2005, 335, emphasis in original). This makes implementation of UNSCR 1325 a particularly challenging task in the field of security and defence and explains, in part, the critique of scholars such as Lombardo and Meier $(2006,151)$, who observed that, even ten years after the Commission's communication, 'gender mainstreaming has not been effectively implemented in the EU', and that EU documents were 'gender-blind' (ibid., 158). Because much remains to be done, it seems important to examine how gender mainstreaming is being implemented in the CSDP and why it has taken hold, because defining the driving forces thus far should provide insights into what might still be needed.

Gender scholars have identified a number of factors that have been conducive to gender mainstreaming within institutions, including a favourable opportunity structure, prior exposure to gender-related issues and the presence of civil society actors (see e.g. Pollack and Hafner-Burton 2000, 439; Lombardo and Meier 2006; Elman 2007). However, in the case of the CSDP, these factors are elusive. In addition to being the most state-centric policy field within the EU to date - one in which unanimity is the predominant mode of decisionmaking - the CSDP is also characterized by a lack of resources (for example, it has no fulltime staff and individual agencies dedicated to gender) (EP 2009a, 7, 2009b, 18). Given these impediments, then, how can we explain the EU's pursuit of gender mainstreaming in the context of the CSDP?

In this paper, we draw on feminist institutionalist approaches (e.g. Mackay, Kenny and 
Chappel 2010; Paantjens 2005; Weiner and McRae 2014) to argue that the impetus for policy change came from individuals and groups from within the EU who were involved in and supported by networks of 'gender entrepreneurs' (Elgström 2000, 464) both above and below the supranational level, but that institutional norms and idiosyncrasies have shaped the implementation of UNSCR 1325 in important ways. Approaching gender mainstreaming in the CSDP from the perspective of feminist institutionalism is an appropriate way to address the gender blindness of institutionalism. Institutionalist scholars, though concerned with institutional change and stability, have for the most part neglected 'the global and regional political trend of incorporation of women in formal institutions' (Mackay, Kenny and Chappell 2010, 579; see also Weiner and McRae 2014, 8-9). As a result, 'the remarkable diffusion of institutional reform strategies such as gender candidate quotas, gender mainstreaming policies, equality blueprints and state feminist initiatives have been almost completely overlooked by the NI [new institutionalist] "mainstream" (Mackay, Kenny and Chappell 2010, 579). In addition, analysis of the implementation of UNSCR 1325 as part of the CSDP also contributes to the burgeoning body of literature on gender mainstreaming in the EU (e.g., Lombardo and Meier 2006; Pollack and Hafner-Burton 2000 or Mazey 2000), which has addressed a great number of policy fields but has ignored the areas of security and defence.

Not only does studying the CSDP contribute to a more complete picture of how questions related to gender equality are addressed within the EU, but it also sheds light on the role of exogenous institutional factors, especially on networks of gender entrepreneurs that have received little attention from institutionalists in general and from feminist institutionalist scholars in particular. It shows how individual agents of change who are embedded in transnational networks can assist institutional development despite structural impediments.

The analysis provided here is based on primary documents, interviews with EU, UN and state officials and interviews with representatives of civil society organizations. We analysed policy documents issued by the European Parliament (EP 2000, 2006, 2009a-b, 2010a, 2010b); by the European Council (Council 2006, 2008a-c, 2009, 2010, 2011, 2012, 2014); by the EU's implementing actors, such as the EU Operation Headquarters (EU Op HQ 2006); by UN agencies (UNIFEM 2008a-b); and documents issued jointly by EU and UN agencies (EU and UNIFEM 2008; EU and UN Women 2012). In addition, we analysed evaluations of the EU's implementation of Resolution 1325 by civil society organizations (Gya 2007; Sherriff and Barnes 2008) and policy documents obtained from gender entrepreneurs whom we 
identified based on frequent references made to them during the interviews and during our analysis (Swedish Government 2006; Isaksson 2012; SWEDINT 2015; Swedish Armed Forces 2016). In addition, between March 2009 and January 2016, we conducted semistructured interviews with representatives from UN Women, the European Commission, the European External Action Service (EEAS), civil society organizations and German and Swedish state agencies. Interviewees were selected with the help of documents and because of their activities as gender entrepreneurs within or outside of the EU institutions. The interviews were transcribed, anonymized and analysed by means of a qualitative content analysis.

The paper begins with a brief introduction to the feminist institutionalist perspective and the theoretical underpinnings of our analysis. We then turn to the implementation of UNSCR 1325 within the framework of the CSDP. We show how gender mainstreaming was integrated in what still is one of the policy fields that are most resistant to the incorporation of gender - that is, the area of security - as a result of internal change drivers within the EU that were supported by networks at different levels. The paper concludes with a summary of our findings and a brief discussion of their implications.

\section{Gender mainstreaming and feminist institutionalism}

Gender mainstreaming is a contested concept. It reflects at least two different frames of reference: gender equality and the mainstream (Walby 2005, 322; see also Verloo 2001; Rees 2005; Benschop and Verloo 2006, 22). Gender mainstreaming promotes 'gender equality through [the] systematic integration of [gender in] all systems and structures, into all policies, processes and procedures, into the organisation and its culture, into ways of seeing and doing' (Rees 2005, 560). When understood in this way, it can be considered a desirable outcome, a strategy or a process (e.g. Beveridge, Nott and Stephen 2000; Rees 2005; Walby 2005; Benschop and Verloo 2006; Cohn 2008; Willett 2010). ${ }^{1}$ Scholars who have analysed the implementation of gender mainstreaming in the field of security, and especially in the context of UNSCR 1325, also point out that 'the contents of the resolution, particularly regarding the themes ... of gender mainstreaming, contain highly contested elements' (Olsson and Gizelis $2015,2)$. They also have found that gender mainstreaming is specifically contested in the

\footnotetext{
${ }^{1}$ However, even among those who favour a particular interpretation, opinions differ as to exactly what is meant by 'outcome', 'strategy' or 'process'. For a presentation of the different positions, see Joachim and Schneiker (2012).
} 
field of security, because the military is a profoundly - if not the most profoundly-male institution (Apelt 2002), hence security policies and its instruments, including peacekeeping, continue to be dominated by men (Conaway and Shoemaker 2008, 10; see also Willett 2010, 151-152). In addition to the structural impediments, feminist scholars have also problematized the Resolution itself and its application. Because it perpetuates the (gender) status quo and reproduces existing inequalities and power relations, Puechguirbal $(2010,184)$ and others (e.g. Gibbings 2011 and Harrington 2011) have questioned its transformative potential. Despite such criticisms, a growing number of studies are seeking to explain the implementation of gender mainstreaming.

Feminist institutionalism, 'which seeks to synthesize feminist insights with the new institutionalist theory' (Weiner and MacRae 2014, 3), offers a viable perspective that makes it possible to reveal the driving forces behind gender mainstreaming within the CSDP. It allows us not only to examine institutional change and development but also to consider 'the machinations of gendered power as both institutional-that is, playing out within institutions-and also institutionalized-i.e., incorporated into the very structure of institutions' (Weiner and MacRae 2014, 3, emphasis in original; see also Paantjens 2005). Because feminist institutionalists draw on rational, historical and sociological versions of new institutionalism eclectically rather than conceiving of them in an exclusive manner (Mackay, Kenny and Chappell 2010, 576), ${ }^{2}$ they, first, offer a notion of change that conforms better with the ways in which gender mainstreaming takes place and the 'Sisyph[ean] labor' to which it has been compared (Benschop and Verloo 2006, 31), involving 'small—often hardwon-gains' (Weiner and MacRae 2014, 2). Rather than as a one-time shock (Mackay, Kenny and Chappell 2010, 582), gender mainstreaming, as depicted by feminist institutionalists, is a process that is gradual rather than abrupt and that involves '... layering, where some elements of existing institutions are renegotiated but other elements remain; [or] conversion, in which existing institutions are redirected to new purposes' (Mackay, Kenny and Chappell 2010, 577, emphases in original).

In addition, this perspective allows us to capture the forces that drive change both within and outside institutions because of the attention that feminist institutionalism pays to the

\footnotetext{
${ }^{2}$ An integrated approach such as the one described is not specific to feminist institutionalism; indeed, it is reflective of the facts that rapprochement in the field has been coming for some time and that 'the development of institutional analysis has muted the conventional distinctions among institutionalisms' (Clemens and Cook 1999, 446).
} 
interaction between institutional structures and actors. According to Mergaert and Lombardo $(2014,4)$, institutional structures provide actors 'with the necessary hierarchical backing, resources, time, personnel decision-making power and adequate knowledge and training to perform the task' (ibid.) and to effectively pursue their agenda. However, institutions are also 'battlegrounds of norms' (Mergaert and Lombardo 2014, 4) that 'constitute important “filters" which may either support or resist policy change' (Mazey 2000, 339; Kantola 2006, 34). Kantola and Squires (2012), for example, identified the 'neoliberal rationale' on which the EU is premised as an institutional impediment to gender mainstreaming, and Kronsell (2005) and Lombardo (2003) drew attention to the entrenched male power and masculine interests. Other scholars, such as Mackay (2009), have regarded prior exposure to genderrelated issues and previous commitment in this area as important institutional prerequisites that determine whether or not gender mainstreaming will be implemented in a particular policy field.

With respect to the actors who have to be committed and strategic change agents (Mackay, Kenny and Chappell 2010, 578), quite a number of studies related to gender mainstreaming emphasize the importance of networks. Studying gender mainstreaming in the EU in several policy areas, Pollack and Hafner-Burton (2000) found 'specific supranational actorsincluding, most notably, the Equal Opportunities Unit of the Commission and the Women's Rights Committee of the European Parliament-[to have] form[ed] the heart of a transnational network of experts and activists in the area of equal opportunities' (pp. 434435), which placed gender mainstreaming on the agendas of Directorate-Generals of the European Commission. Other scholars have emphasized that the role of civil society actors and their access to political institutions have been decisive in determining how gender mainstreaming gets implemented (Joachim and Schneiker 2012) — that is, whether institutions simply engage in 'tinkering' without bringing about any more fundamental changes or whether they undergo transformations (see e.g. Rees 1995). Building on the work of these scholars, we conceive of networks as central transmission belts through which gender mainstreaming is carried into and diffused within institutions.

Such networks, which comprise coalitions of individual and collective actors who promote gender mainstreaming (Elgström 2000, 464), cross institutional boundaries and span a variety of sectors. Although shared values may be these participants' motivation for interaction, their motivation may also be strategic (Keck and Sikkink 1998). In addition to a normative commitment to gender mainstreaming, cooperation among network members may be driven 
by deficiencies in information resources, a need for 'strategic direction and co-ordination' (Lowndes and Skelcher 1998, 315) or a need for alliances with external actors to legitimate new ideas and practices within a given actor's organization (Barnett and Finnemore 1999, 710). Although networks may originate and be composed of actors solely from within an institution, feminist institutionalists also draw attention to the 'external drivers of change' (Mackay, Kenny and Chappell 2010, 582). According to Scott and Davis, wider organizational environments and the networks that are part of them not only 'shape, support and infiltrate organizations' (Scott and Davis 2007, 31), they can also be catalysts for new ideas, particularly if actors from within an institution maintain relationships and engage in networks outside of it. These 'complex collective agent[s]', as Crouch and Farrell (2004) refer to them, may then be in a position to 'simultaneously play different games' (Crouch and Farrell 2004, 24) and transfer their 'experience from different action spaces' (ibid., 34) or policy domains. In this case, individual gender entrepreneurs assume a boundary role; they become important linking pins and knowledge brokers that mediate the flow of knowledge and information among actors (Boari and Riboldazzi 2014, 683) within and among networks.

In terms of the CSDP, we would expect networks to have been a crucial factor in the implementation of gender mainstreaming based on UNSCR 1325. Given that policies on gender equality had been virtually absent from the former second pillar of the Common Foreign and Security Policy prior to the adoption of the Comprehensive Approach in 2008, the impetus for the gender mainstreaming of security and defence must have originated in the wider environment, which makes it necessary to 'take into account different sorts of institutions and how they interact and interlock with others in dense institutional environments' (Mackay, Kenny and Chappell 2010, 582).

\section{UNSCR 1325 and gender mainstreaming within the CSDP}

The Comprehensive Approach, adopted in 2008, was the EU's first substantive policy response to UNSCR 1325. The plan envisions 'a three-pronged approach to protect, support and empower women in conflict' (Council 2008a, 11). It consists of efforts, first, to 'integrate women, peace and security issues in [the EU's] political and policy dialogue with partner governments, particularly of countries affected by armed conflict, in post-conflict situations or situations of fragility'; second, to 'mainstream a gender equality approach in its policies and activities, especially in the context of crisis management and in its long-term 
development cooperation'; and, third, to 'support specific strategic actions ... targeted at protecting, supporting and empowering women' (Council 2008a, 11). Before the adoption of the Comprehensive Approach, the issue of gender mainstreaming within the CSDP had been addressed only sporadically, such as in measures on the operational level, occasional appointments of gender advisors to EU missions ${ }^{3}$ and the provision of gender training prior to deployment (Gya 2007). ${ }^{4}$ In 2006, the European Council adopted a checklist for gender mainstreaming within the CSDP on the policy level (Council 2006) that provided guidelines for 'when and where to mainstream gender'. However, gender entrepreneurs criticized this checklist for its noncommittal stance, its vagueness and its lack of specific instructions as to how gender mainstreaming might be achieved in practice (Gya 2007, 6).

Since 2008, the Council has developed several strategies to supplement the Comprehensive Approach by identifying specific steps for gender mainstreaming the CSDP. These strategies are specified in the conclusions of the document 'Implementation of UNSCR 1325 as reinforced by UNSCR 1820 in the context of ESDP' (Council 2008b) and in the 'EU guidelines on violence against women and girls and combating all forms of discrimination against them' (Council 2008c). The former document specifies how to consider gender in the planning and implementation of the European Security and Defence Policy (ESDP) by, among other things, reflecting on gender issues or enlisting gender expertise (Council 2008b, $6,8)$. The guidelines outline the steps needed to accomplish this goal (Council 2008c).

In 2009, in light of the Council's conclusions contained in a follow-up document'Implementation of UNSCR 1325 and UNSCR 1820 in the context of training for the CSDP missions and operations recommendations on the way forward' (Council 2009) - some Council members called upon policymakers to develop 'common/standard elements for a training curriculum on gender' (Council 2009, 4). One year later, Council members agreed on a set of indicators to be used in implementing the Comprehensive Approach that would 'aim at [s]trengthening the EU accountability of implementing its commitments on women, peace and security' and '[d]etecting progress and achievements' and 'gaps and weaknesses' while

\footnotetext{
${ }^{3}$ For example, the first gender advisor to the EU Operational Headquarters was appointed for the EU's military operation in the Democratic Republic of the Congo (EUFOR DR Congo) in 2006 (EU Op HQ 2006).

${ }^{4}$ A pre-deployment gender training package was issued for the European Union Police Mission (EUPOL) in Afghanistan in 2007 (Gya 2007), and the Policy Unit of its Directorate-General 9 conducted a gender mainstreaming seminar for heads of CSDP missions (Gya 2007, 5). The first training course on gender and CSDP was conducted in Hungary in 2007 with the support of the German EU Presidency (Gya 2007, 4).
} 
also aiming at '[f]acilitating subsequent policy making and prioritization of actions, as well as possible benchmarking' (Council 2010, 7). Based on these indicators, which are currently being updated (authors' personal interview, 19 November 2015), the EU and its member states regularly provide reports of progress on the implementation of UNSCR 1325 (Council 2011, 2014). In September 2015, the EEAS appointed Mara Marinaki as the first Principal Advisor on Gender and on the Implementation of UNSCR 1325. At that time, Marinaki asserted that she would 'work to enhance the visibility and effective prioritization of gender and WPS [women, peace and security] in the EU's external action and to assist the work of the UN, in close consultation with all UN services and agencies' (EEAS 2015).

The fact that the EU has proceeded to implement Resolution 1325 in the CSDP and the ways in which this was done require some explanation. The 'transform[ation of] ... institutional gender norms and behaviours that create inequalities' (Mergaert and Lombardo 2014, 4) posed not only challenges in light of structural, personal and institutional barriers discussed in the previous section, but was also likely to be met with resistance (Stratigaki 2005).

\section{External networks and the implementation of UNSCR 1325 in the CSDP}

Change within the CSDP and action in response to UNSCR 1325 were instigated from outside the organization. Actors who participated in networks below and above the EU level played a crucial role in championing gender mainstreaming in the field of security and defence. However, their actions and scope were conditioned by the institutional settings of the CSDP.

The year 2008 is often referred to within the EU as a 'watershed' moment with respect to UNSCR 1325 (EP 2010a, 33). Initiatives to advance gender mainstreaming within the CSDP had been introduced earlier but did not result in a comprehensive policy. The European Parliament (EP) 'had long acted as one of the primary advocates of a more forceful EU policy on women's issues' (Pollack and Hafner-Burton 2000, 436; see also EP 2000, 3, 2006, 2, 8-9, 2009a, 5, 2009b, 2010a, 46-47, 2010b, 4). It vowed to 'ensure a constant pressure' on Council and Commission members and on the Security and Defence Subcommittee (SEDE) 'to strengthen EU mechanisms towards implementing [UNSCR] 1325 and [the subsequent UNSCR] 1820' (EP 2010a, 47) and recommended, among other policy measures, the establishment of 'gender-specific indicators which can be monitored during conflicts and which could [be] incorporated into new foreign policy and development instruments or serve 
as early warnings' (EP 2006, 10). As one might expect based on the recent literature on international organizations as actors, the EP legitimated its action relative to UNSCR 1325 with reference to 'other international bodies with proficiency in the field', such as the Council of Europe, NATO, the UN and the Organization for Security and Co-operation in Europe (OSCE) (EP 2006, 10, 2009b, 20). In addition, the EP justified gender mainstreaming in the CSDP in terms of 'operational effectiveness' (EP 2009b, 21, 2009a, 7, 9), thereby drawing on the work of gender entrepreneurs at European think tanks who provided arguments for implementing Resolution 1325 and with whom representatives of the EP exchanged views in seminars related to the role of women in armed conflict (EP 2010a, 47).

A study requested by the EP and prepared by Giji Gya, a former staff member of the European think tank International Security Information Service Europe (ISIS Europe), identified 'a gender perspective in a military mission' as being of 'paramount importance' given the high number of civilian missions (EP 2009b). Adopting a similar line of argument were Judy Batt and Johanna Valenius, two gender experts from the Institute for Security Studies in Brussels who assessed gender mainstreaming in previous ESDP missions in Bosnia and Herzegovina. In their view, gender mainstreaming 'is a means of both improving the operational effectiveness of crisis management missions and enhancing human rights' (Batt and Valenius 2006, 3). By involving and 'increasing the visibility of women in responsible positions', the EU 'can help offset the tendency to[wards] "retraditionalisation" of gender roles that is often found in post-conflict societies' (ibid., 11).

Quite a number of scholars have noted that framing gender mainstreaming either in neoliberal terms - 'emphasizing individualism and free markets'-or in interventionist terms'endorsing intervention of states and international organizations in the market-place in pursuit of social goals such as sexual equality'- has been essential to its advancement with respect to common market policies within the EU (e.g. Pollack and Hafner-Burton 2000, 435). Such framing also applies to the CSDP, in which gender mainstreaming is presented by advocates as a means of enhancing EU missions. However, such a position has been criticized by feminist scholars, particularly those who draw on postcolonial perspectives to question the transformative potential of Resolution 1325. In their view, rather than leading to the inclusion of women, this resolution has exclusive effects, constrains agency, reproduces existing power asymmetries and fails to prevent sexual violence by peacekeepers (e.g. Gibbings 2011; Harrington 2011).

According to Weiner and MacRae $(2014,13)$, the fact that the Council did not take action in 
line with UNSCR 1325 and respond to the pressure exerted by the EP reflects institutional particularities of the EU. These authors note that 'some of the institutional actors' [among them the European Parliament] lack the fortitude to overturn a "logic of appropriateness" - to which more powerful actors (e.g. the Council of the European Union) subscribe-that dictates discarding gender (Weiner and MacRae 2014, 13, in reference to Allwood 2014).

In contrast to policy fields in which the EP has decision-making power, its role within the CSDP is limited to that of a watchdog. However, the European Parliament's never-ending 'Sisyphus' labor' (Benschop and Verloo 2006, 31) can be regarded as a part of efforts to raise the kind of awareness that gender mainstreaming requires and to pave the way for more powerful actors to tie gender mainstreaming into the EU's security and defence policy.

"Actors in positions of power can use their authority to change the "rules of the game", increasing their own capacities for political actions while diminishing the power and authority of their institutional rivals' (Mackay, Kenny and Chappell 2010, 579, in reference to Pierson 2004, 36). In the case of the CSDP, the actors in positions of power are the member states. They can shape the agenda by identifying a list of priorities for their tenure, especially if they hold the Presidency, as was the case with France, which, according to observers, laid the groundwork for the Comprehensive Approach in the autumn of 2008 (EP 2010a, 35). Together with what was then still UNIFEM but is now part of UN Women, and with support from the Council and the European Commission, the French Presidency organized an international conference entitled 'From Commitment to Action-The EU Delivering to Women in Conflict and Post-Conflict: Implementing SCR 1325 and 1820 in EU Missions: Improving Immediate and Long-Term Security for Women'. The conference was intended to evaluate the role of gender and gender mainstreaming in connection with EU missions, particularly in the Democratic Republic of the Congo and during the European Union Rule of Law Mission in Kosovo (EULEX Kosovo), and to advance proposals for further action, such as by introducing accountability and monitoring mechanisms.

The French Presidency's initiative showed that the intergovernmental structure of the CSDP can act as a constrain to the success of gender mainstreaming efforts but can be viewed as a resource as well. Also in 2008, the French Presidency and UNIFEM organized several meetings that led to the establishment of a network of gender advisors and gender focal points for the two organizations (EU and UNIFEM 2008; UNIFEM 2008a-b). Their exchange of 'best practices and lessons identified from all missions and operations' (EP 2010a, 61) became more regularized over time. In 2009 it culminated in the creation of the 
Informal Task Force on Women, Peace and Security, which consists of ' 15 gender staff and gender focal points across all the EU institutions working on gender, peace and security' and is also open to other actors (EP 2010a, 32). The Informal Task Force provides a platform for gender entrepreneurs from the EU, from civil society and from the UN to move forward implementation of UNSCR 1325 within the CSDP. The activities of this task force support the arguments made by Crouch and Farrell (2004) and by Pollack and Hafner-Burton (2000), who regarded networks as the drivers of institutional change because they introduce new ideas.

UN Women played a particularly important role in this task force by providing technical expertise and advice on the implementation of UNSCR 1325 in general and by revising and elaborating the list of indicators that the EU had adopted in particular (authors' interview, 19 November 2015). Given that resources for and experience in implementing gender mainstreaming within security policy were lacking, the EEAS was a willing recipient of new impetus from outside (authors' interview, 8 January 2016), as were policymakers, who are 'always grateful for the expertise [the UN could] provide on the formulation of gender policies for the EU' (authors' interview, 19 November 2015). The interviews we conducted with representatives of the EU supported the theoretical claim that the idea of gender mainstreaming was carried into the CSDP from outside. The transnational network of gender entrepreneurs helped proponents of UNSCR 1325 within the EU gain acceptance for greater recognition of gender in policies related to security and defence. Cooperation between UN and EU actors was not only motivated by the lack of resources within the EU but, as one of our interviewees put it, was also facilitated by the fact that these actors 'share similar values especially on women, peace and security' (authors' interview, 8 January 2016).

Both the benefits and the shared values further stimulated development, which led to the decision to place the interaction on firmer ground by adopting a memorandum of understanding in April 2012 in order 'to mutually consolidate, develop and structure their cooperation in areas of common concern' (EU and UN Women 2012, 2). The relationship between the EEAS and the UN in matters relating to UNSCR 1325 can be considered unique. Not only the interviews we conducted but also the documents we analysed suggest that both the UN and gender entrepreneurs within the EEAS and 'the concentration of expertise on gender equality and gender empowerment within UN Women are responsible for [the common goal of making gender a priority]. The agency is acknowledged as a privileged source of expertise unmatched by other actors, including civil society organizations, which 
policymakers nevertheless also consulted' (authors' interview, 19 November 2015).

Involvement of civil society organizations has been deemed critical for gender mainstreaming to take hold within institutions and to materialize in the form of specific policy measures (Joachim and Schneiker 2012). Civil society organizations also played an important role with respect to integrating gender into the CSDP. According to Giji Gya, the author of the EP study mentioned earlier, it is these organizations that have 'pushed the EU to the effective implementation of benchmarks for [UNSCR] 1325' (EP 2010a, 19), the development of indicators of sexual violence and the continuation of 'consultations [on the subject] already [in existence] for a few years in the EU institutions with NGOs, civil society and UN agencies' (EP 2009b, 42). In this respect, two civil society organizations in particular assumed a prominent role. ISIS Europe frequently provided feedback on the implementation process, was commissioned by EU institutions to prepare reports and offered recommendations. The European Peacebuilding Liaison Office (EPLO), a platform for European NGOs, networks and think tanks, in turn, acted as a clearing house that documented and provided information about EU policy initiatives and offered policy advice and specific recommendations. Also, the two organizations-or, rather, their representatives - together were often invited to attend conferences and workshops organized by the General Secretariat of the Council. The activities of ISIS Europe and EPLO were promoted and facilitated by prominent individual gender entrepreneurs who were themselves members of various networks.

Margot Wallström can be regarded as such an 'active broker' because of her previous appointment as the European Commissioner for the Environment and, later, as the UN Special Representative on Sexual Violence in Conflict. She often attended EU meetings and consultations with Council and Commission staff and with civil society organizations devoted to issues related to gender and armed conflict (EP 2010a, 10). In her report to the European Parliament, Gya noted that 'Wallström decided to work under her [UNSCR] 1820 based mandate in a pro-active direction and provide, via a newly developed Team of Legal Experts, international assistance to institutional and capacity building' (EP 2010a, 16). On the EU level, she recommended 'a "Personal (EU) Advisor to act as a Personal Interlocutor" to her role' (EP 2010a, 48).

Brigadier General (now Major General) Karl Engelbrektson also played an important role in this process. He is symbolic of the actors that Crouch and Farrell may have had in mind when they wrote about the role of networks for institutional change and about actors who are active 
in different institutional environments and transfer their experience from 'different action spaces' (Crouch and Farrell 2004, 35). A member of the Swedish Armed Forces, a former commander of the Nordic Battlegroup ${ }^{5}$ and the Swedish representative to the EU Military Committee, Engelbrektson was 'a strong voice in the military for [UNSCR] 1325 to become a natural approach to EU policy and implementation' and 'an advocate for gender coaching' for heads of missions (EP 2010a, 62). Charlotte Isaksson, also from Sweden, served as the first Gender Advisor to the EU, a role she assumed during EUFOR RD Congo in 2006. Isaksson saw it as her 'mission ... to integrate UNSCR 1325 and 1820 into the military so that all soldiers and officers deployed are trained to work in order to strengthen women's human rights, security and participation' (Isaksson 2012). In this role, she was also able to draw from experience as Senior Gender Advisor to the Director of Operations of the Swedish Armed Forces and as Gender Advisor to the Nordic Battlegroup. Isaksson, exemplifies the role of gender advocate quite well and how they are or become members of different networks from where they exert influence. As of recently she serves as senior advisor to the Principal Advisor on Gender and UNSCR 1325 of the European External Action Service (Supreme Headquarters Allied Powers Europe, SHAPE 2016).

It is perhaps no coincidence that Swedish citizens, and members of the Swedish Armed Forces in particular, played a prominent role in this process. It is a finding that makes us aware that the structures in which gender mainstreaming is implemented within the CSDP extend to levels above and below EU institutions and that new impetus for change is coming from national levels or the international level. EU member states with strong gender mainstreaming agendas and policies on the domestic level that have also previously assumed leadership in the advancement of gender issues on the international level are often drivers of gender mainstreaming within the CSDP. In October 2006, the government of Sweden was one of the first governments to adopt a national gender action plan (Swedish Government 2006), and agencies of the Swedish government worked with the Swedish Armed Forces and civil society organizations and used funding from the European Commission to establish the network Genderforce in order to improve Swedish international relief operations and peacekeeping missions by ensuring the participation of women (EC 2013).

In addition, Sweden, together with Finland and Norway, founded the Nordic Centre for

\footnotetext{
${ }^{5}$ One of the EU's Battlegroups to assist it in crisis management (Swedish Armed Forces 2016).
} 
Gender in Military Operations (Egnell, Hojem and Berts 2014, 68), 'a common platform for training and education, information sharing and a comprehensive approach including gender' (SWEDINT 2015, 5). Sweden's national record helps to explain the fact that the country has assumed leadership in this area within the EU, but it should also be noted that Sweden was supported by like-minded states such as Denmark, as well as by Finland, which had started to push for gender mainstreaming on the EU level early in the process (Pollack and HafnerBurton 2000, 436). These three countries also played a major role in the appointment of the EEAS's Principal Advisor on Gender and the implementation of UNSCR 1325 in late 2015, building inter-institutional peer pressure by pointing to NATO, which already had such an advisor at the time (authors' interview, 19 November 2015).

The activities of the various gender entrepreneurs involved in this process allow us to identify the drivers of institutional change, but they do not explain why we see institutional acceptance of UNSCR 1325 rather than resistance to it. According to feminist institutionalist scholars, gender mainstreaming is often interpreted in line with institutional norms and rules. Because there is no clear definition of what gender mainstreaming actually entails, policy actors can adapt gender policy objectives 'to the policy domain in which it takes shape' (Meier and Celis 2011, 472; see also Joachim and Schneiker 2012). However, in some cases, they can also use gender mainstreaming to advance other political and/or economic priorities (Elgström 2000; Stratigaki 2005; Weiner and MacRae 2014, 6). Support for this assertion can be found in the CSDP itself. The implementation of UNSCR 1325 provided an opportunity to continue building the EU's reputation as an international security actor. In the document listing the indicators for the Comprehensive Approach, the Council noted that these indicators would not only facilitate 'clear communication about the implementation of the relevant EU policy' but would also improve 'EU visibility' (Council 2010, 7). In addition, UNSCR 1325 helps to shape the image of the EU as a unique and different actor. In a study conducted for the Slovenian Presidency, the EU was described as

one of [the few international entities that bring] all the elements of a multilateral approach to armed conflict. It is this potential for the EU to be a positive actor in conflict prevention and the promotion of human security [that] makes the EU an important player in responding to the issue of women and armed conflict. The EU brings considerable added value as a positive actor in responding to women and armed conflict, closely mirroring the EU's potential as an actor in conflict prevention (Sherriff and Barnes 2008, 4). 
Sherriff and Barnes, the authors of the study, also emphasized what in their view set the EU apart from other international organizations. Not only did they conceive its members to be 'amongst the most progressive countries in the world when it comes to gender', but they also praised the EU for its engagement regarding gender. In this respect, Sherriff and Barnes pointed to the EU's '[c]ommitment to and progress on gender equality and women's rights', 'the [d]iversity of instruments in the diplomatic, defence and development spheres' and the fact that it is a '[1]arge diplomatic block acting as one in many international forums', the '[1]argest donor of humanitarian and development resources' and 'the [w]orld's largest trading block' (Sherriff and Barnes 2008, 4).

The poster child role that the EU was able to assume by gender mainstreaming its CSDP was echoed by others. For example, in her study prepared for the EP, Giji Gya, in reference to Sherriff and Barnes, stressed 'the considerable added value' the EU could bring 'as a positive actor in responding to women and armed conflict', mirroring the EU's overall 'potential as an actor in conflict prevention (EP 2009b, 21). Batt and Valenius, in their assessment of the gender mainstreaming of CSDP missions, noted how the EU can 'set an example for the local community on gender equality' by including women in military and police missions, but at the same time warned of the losses it would suffer in 'credibility and effectiveness' if 'the EU itself does not practise what it preaches' (Batt and Valenius 2006, 11).

The emphasis on the EU's unique qualities and the potential reputational and credibility gains associated with the organization's leadership can be viewed, on the one hand, as an argument directed at sceptics of gender mainstreaming security policies on the inside. On the other hand, as it can be seen as a signal to actors outside the EU and an expression of the EU's 'strong ... urges for autonomous action, visibility and differentiation' (Koops 2012, 173). In either case, it highlights how network members combined normative arguments with strategy and how they made use of institutional particularities to garner acceptance of Resolution 1325. Among these institutional particularities was what has been referred to as the 'crosspillarization' of the CSDP - that is, an overlap of thematic policies and programming on external actions and the responsibility for them held simultaneously by different DirectorateGenerals or committees (EP 2009b, 17). Although the pillar structure has been abolished since the adoption of the Treaty of Lisbon, pillarization continues to have a number of effects, especially on issues of crisis management, conflict prevention, post-conflict reconstruction, peacebuilding and combating organized crime. These issues touch upon the responsibilities of both the Council and the Commission and involve instruments from other policy areas, most 
notably development, but also trade, justice, freedom and security (ibid., 18). Because of this fragmentation, cross-pillarization has occasionally been identified as an impediment to the consistent implementation of gender mainstreaming (EP 2009b, 43).

Nevertheless, cross-pillarization is not entirely negative. As critics themselves acknowledge, it also can produce synergistic effects or, to express it in more functional terms, spillover effects. In the context of the CSDP, cross-pillarization brings policy areas and institutions into play that have already been predisposed to gender issues and have thus laid the groundwork for continuing involvement in such issues. For example, in 2006, Council Secretariat and Commission staff together produced a concept for disarmament, demobilization and reintegration and 'soundly mainstreamed gender' into it (EP 2009b, 24). More generally, gender entrepreneurs regard the 'security development agenda' of the EU as an important nexus. In their eyes, the fact that gender mainstreaming has already been institutionally inscribed into development can have positive effects in terms of leading to a spillover to security issues (Elgström 2011). In the Comprehensive Approach, the EU itself refers to its 'longstanding engagement to promote gender equality and women's rights in its external policy' (Council 2008a, 21) and to its past internal 'policy commitments to promote the role of women in peace building' (Council 2008a, 4) as building blocks for the gender mainstreaming of the CSDP. Although in this context cross-pillarization is thought of in a more narrow sense, our analysis shows that much of the advancement of gender mainstreaming in the CSDP that has been achieved can be attributed to synergistic effects resulting from the linkages that EU actors maintain with others outside the EU and the respective policy field.

\section{Conclusion}

In this paper, we drew on feminist institutionalism to provide an explanation of the implementation of UNSCR 1325 on women, peace and security. We showed that a transnational network of gender entrepreneurs from both within and outside the EU played an important role in the implementation of gender mainstreaming in the CSDP. By exchanging expertise and using institutional idiosyncrasies, these entrepreneurs were able to overcome obstacles within the CSDP, including a lack of resources and of prior experience with gender or gender mainstreaming.

Our study makes several contributions to what has become an impressive body of literature on gender mainstreaming. For one, the findings support previous research that identified 
essential prerequisites for gender mainstreaming, such as the crucial role of committed and like-minded individuals and of institutional opportunities. In the context of the CSDP, the leadership assumed by the European Parliament, individual states such as France and Sweden and civil society organizations played a critical role, as did the reputational benefits that EU actors have associated with implementation of UNSCR 1325. However, the evidence presented here also points to some important differences. In the CSDP, the external institutional context was pivotal to the advancement of gender mainstreaming in the policy field: whereas UN Women, for example, compensated for the lack of technical expertise in the CSDP, the UN more generally served as a role model in its implementation. This is somewhat ironic, because quite a number of feminist scholars have been rather critical of the implementation of Resolution 1325 within the UN.

From a comparative perspective, however, the advancements made and the knowledge accumulated over the years in relation to gender mainstreaming have proved sufficient to use them as leverage within the EU. The same can be said with regard to the national level, where the gendering of security policies often proceeds at a slower pace than supporters would like, involving discursive rather than substantive change (Joachim and Schneiker 2012). Nonetheless, and similar to the case of the UN, it seemed to be enough to offer a template for individual governments whose support gender entrepreneurs had enlisted to push for gender mainstreaming at the European level and its introduction into the security and defence policy framework.

In the literature on gender mainstreaming, the interaction of institutions and their coupling through cross-boundary networks, though an often acknowledged and increasingly political practice, is still largely uncharted territory in need of further exploration. Our analysis of gender mainstreaming in the CSDP offers some preliminary insights into how interactions and cross-boundary networks can act as catalysts for change within less amicable or even adversarial policy fields. Yet much work remains to be done to examine in greater detail how gender mainstreaming is filtered through cross-boundary networks, how these networks contribute to and reinforce certain privileged understandings of gender mainstreaming and how the distribution of power among and within such networks impinges upon the outcome. Feminist institutionalism can provide a useful lens in attempting to answer these questions, because not only does this approach take institutions and their respective constitution seriously, but it is particularly sensitive to the gendered scripts that are inscribed into them. The primary aim of this paper was to determine how policies and structures within the EU have changed without simply assuming that gender mainstreaming is a good thing in and of 
itself or that gender entrepreneurs accomplished a herculean task. Our findings point to important institutional factors that have received little attention in the gender mainstreaming literature and also offer insights into the implementation of Resolution 1325 in regional organizations. But our results are also comparable to those of other studies insofar as the achievements in the EU are deemed by the gender entrepreneurs we interviewed to be still rather modest and to have thus far only arrived at the policy level instead of having trickled down to the field. More analysis will be needed to determine the extent to which this assessment is fair. Case study evidence of EU missions, for example, will provide more useful information that allows us to determine whether the incorporation of UNSCR 1325 into the CSDP has actually led to a change in behaviour and altered security and military cultures and power relations.

\section{References}

Allwood, Gill (2014) 'Gender mainstreaming and EU climate change policy', European Integration online Papers (EIoP), 18:Art. 6

Barnett, Michael N and Martha Finnemore (1999) 'The politics, power, and pathologies of international organizations', International Organization, 53:4, 699-732

Batt, Judy and Johanna Valenius (2006) 'Gender mainstreaming: implementing UNSCR 1325 in ESDP missions'. Paris: EU Institute for Security Studies, <http://www.iss.europa.eu/uploads/media/analy152old.pdf>, accessed 15 February 2016

Benschop, Yvonne and Mieke Verloo (2006) 'Sisyphus' sisters: can gender mainstreaming escape the genderedness of organizations?', Journal of Gender Studies, 15:1, 19-33

Beveridge, Fiona, Sue Nott and Kylie Stephen (2000) 'Mainstreaming and the engendering of policy-making: a means to an end?', Journal of European Public Policy, 7:3, 385-405

Boari, Cristina and Federico Riboldazzi (2014) 'How knowledge brokers emerge and evolve: the role of actors' behaviour', Research Policy, 43:4, 683-695

Booth, Chris and Cinnamon Bennett (2002) 'Gender mainstreaming in the European Union: towards a new conception and practice of equal opportunities?', European Journal of Women's Studies, 9:4, 430-446

Clemens, Elisabeth S and James M Cook (1999) 'Politics and institutionalism: explaining durability and change', Annual Review of Sociology, 25, 441-466

Cohn, Carol (2008) 'Mainstreaming gender in UN security policy: A path to political transformation?' in Shirin M Rai and Georgina Waylen (eds) Global governance: feminist 
perspectives (Houndmills, United Kingdom: Palgrave Macmillan), 185-206.

Conaway, Camille P and Jolynn Shoemaker (2008) Women in United Nations peace operations: increasing the leadership opportunities (Washington, D.C.: Women In International Security, Georgetown University)

Council (2006) 'Check list to ensure gender mainstreaming and implementation of UNSCR 1325 in the planning and conduct of ESDP operations', 12086/06, Brussels: Council of the European Union, 27 July 2006,

<http://www.eupolcopps.eu/sites/default/files/u2/Checklist\%20on\%20UNSCR\%201325\% 20in\%20ESDP\%20Ops.pdf>, accessed 15 February 2016

Council (2008a) 'Comprehensive approach to the EU implementation of the United Nations Security Council Resolutions 1325 and 1820 on women, peace and security', 15671/1/08 REV 1, Brussels: Council of the European Union, 1 December 2008, <http://www.consilium.europa.eu/ueDocs/cms_Data/docs/hr/news187.pdf〉, accessed 15 February 2016

Council (2008b) 'Implementation of UNSCR 1325 as reinforced by UNSCR 1820 in the context of ESDP', 15782/3/08, REV 3, Brussels: Council of the European Union, 3 December 2008,

<http://register.consilium.europa.eu/pdf/en/08/st15/st15782-re03.en08.pdf>, accessed 15 February 2016

Council (2008c) 'Mainstreaming human rights and gender into European security and defence policy', Brussels: Council of the European Union, <http://www.consilium.europa.eu/ueDocs/cms_Data/docs/hr/news144.pdf>, accessed 15 February 2016

Council (2009) 'Implementation of UNSCR 1325 and UNSCR 1820 in the context of training for the ESDP missions and operations: recommendations on the way forward', Brussels: Council of the European Union, 30 September 2009,

<http://register.consilium.europa.eu/pdf/en/09/st13/st13899.en09.pdf〉, accessed 15 February 2016

Council (2010). 'Indicators for the Comprehensive Approach to the EU implementation of the United Nations Security Council Resolutions 1325 and 1820 on women, peace and security', 11948/10, Brussels: Council of the European Union, 14 July 2010.

<http://register.consilium.europa.eu/pdf/en/10/st11/st11948.en10.pdf>, accessed 15 February 2016

Council (2011) 'Report on the EU-indicators for the Comprehensive Approach to the EU 
implementation of the UN Security Council UNCRs 1325 \& 1820 on women, peace and security', 9990/11, Brussels: Council of the European Union, 11 May 2011, $<$ http://eeas.europa.eu/archives/features/features-working-women/working-withwomen/docs/05-eu-indicators-comprehensive-approach-eu-implementat_en.pdf>, accessed 15 February 2016

Council (2014) 'Second report on the EU-indicators for the Comprehensive Approach to the EU implementation of the UN Security Council Resolutions 1325 \& 1820 on women, peace and security', 6219/14, Brussels: Council of the European Union, 6 February 2014, <http://www.europarl.europa.eu/meetdocs/2009_2014/documents/droi/dv/1414_2ndreporti ndicators_/1414_2ndreportindicators_en.pdf>, accessed 15 February 2016

Crouch, Colin and Henry Farrell (2004) 'Breaking the path of institutional development? Alternatives to the new determinism', Rationality and Society, 16:1, 5-43

EC (1996) 'Incorporating equal opportunities for women and men into all community policies and activities', $\operatorname{COM}(96) 67$ final, Brussels: Commission of the European Communities, 21 February 1996, <http://aei.pitt.edu/3991/1/3991.pdf>, accessed 15 February 2016

EC (2013) 'Conquering a new field: integrating the gender dimension into international missions', Stockholm: Genderforce Sweden, <http://ec.europa.eu/employment_social/equal_consolidated/data/document/Repeat/SEConquering\%20a\%20new\%20field.pdf>, accessed 15 February 2016

EEAS (2015) 'EU statement: 15th anniversary and global review of UNSCR 1325', New York, 13 October 2015, <eeas.europa.eu/statements-eeas/2015/151013_05_en.htm>, accessed 15 February 2016

Egnell, Robert, Petter Hojem and Hannes Berts (2014) Gender, military effectiveness, and organizational change: the Swedish model (Houndmills, United Kingdom: Palgrave Macmillan)

Elgström, Ole (2000) 'Norm negotiations: the construction of new norms regarding gender and development in EU foreign aid policy', Journal of European Public Policy, 7:3, 457476

Elman, R Amy (2007) Sexual equality in an integrated Europe: virtual equality (New York: Palgrave Macmillan)

EP (2000) 'European Parliament resolution on participation of women in peaceful conflict resolution (2000/2025[INI]), Brussels: European Parliament, $<$ http://www.europarl.europa.eu/sides/getDoc.do?pubRef=-//EP//TEXT+TA+P5-TA- 
2000-0541+0+DOC+XML+V0//EN\&language=EN>, accessed 15 February 2016

EP (2006) 'Women in armed conflicts and their role in post-conflict reconstruction: European

Parliament resolution on the situation of women in armed conflicts and their role in the reconstruction and democratic process in post-conflict countries (2005/2215[INI])', Brussels: European Parliament, <http://www.europarl.europa.eu/sides/getDoc.do?pubRef=-//EP//NONSGML+TA+P6TA-2006-0245+0+DOC+PDF+V0//EN>, accessed 15 February 2016

EP (2009a) 'Gender mainstreaming in EU external relations: European Parliament resolution of 7 May 2009 on gender mainstreaming in EU external relations and peacebuilding/nation-building (2008/2198[INI])', Brussels: European Parliament, 7 May 2009, $<$ http://www.europarl.europa.eu/sides/getDoc.do?type=TA\&reference=P6-TA-20090372\&language=EN\&ring=A6-2009-0225>, accessed 15 February 2016

EP (2009b) 'Gender mainstreaming and empowerment of women in EU's external relations instruments', Brussels: European Parliament, <http://www.pedz.uni-mannheim.de/daten/edz-ma/ep/09/EST25671.pdf>, accessed 15 February 2016

EP (2010a) 'Implementation of EU policies following the UN Security Council Resolution 1325', Brussels: European Parliament, <http://www.europarl.europa.eu/RegData/etudes/etudes/join/2010/410205/EXPODROI_ET(2010)410205_EN.pdf>, accessed 15 February 2016

EP (2010b) '10th anniversary of UN Security Council Resolution 1325 on women and peace and security: European Parliament resolution of 25 November 2010 on the 10th anniversary of UN Security Council Resolution 1325 (2000) on women, peace and security', Brussels: European Parliament, 25 November 2010, $<$ http://www.europarl.europa.eu/sides/getDoc.do?pubRef=-//EP//NONSGML+TA+P7TA-2010-0439+0+DOC+PDF+V0//EN>, accessed 15 February 2016

EU and UN Women (2012) 'Memorandum of understanding between the European Union and the United Nations Entity for Gender Equality and the Empowerment of Women (UN Women)', Brussels: European Union and UN Women, 16 April, <http://www.enpi-info.eu/library/sites/default/files/attachments/un-woman_en.pdf>, accessed 15 February 2016

EU and UNIFEM (2008) 'From commitment to action: the EU delivering to women in conflict and post-conflict: implementing SCR 1325 and 1820 in EU missions: improving immediate and long-term security for women', Brussels: European Union and United 
Nations Development Fund for Women, 10 October 2008,

<http://www.consilium.europa.eu/uedocs/cmsUpload/27_FR_Pres_UNIFEM_Conf_Repor

t_Oct_10_EN_FINAL.pdf>, accessed 15 February 2016

EU Op HQ (2006) 'Final report on gender work inside EUFOR RD Congo', Potsdam, Germany: EU Operation Headquarters, 15 December 2006,

<http://www.honvedelem.hu/files/9/8008/eu_operation_headquarters_final_gender_report _eufor_rd_con.pdf>, accessed 15 February 2016

Gibbings, Sheri L (2011) 'No angry women at the United Nations: political dreams and the cultural politics of United Nations Security Council Resolution 1325', International Feminist Journal of Politics, 13:4, 522-538

Gya, Giji (2007) 'The importance of gender in ESDP', European Security Review, 34, <http://www.europarl.europa.eu/meetdocs/2004_2009/documents/dv/170/170707/170707i sisgender_en.pdf>, accessed 15 February 2016

Harrington, Carol (2011) 'Resolution 1325 and post-cold war feminist politics', International Feminist Journal of Politics, 13:4, 557-575

Isaksson, Charlotte (2012) 'GenderForce: why didn't we do this before?', OpenDemocracy.net, <http://www.opendemocracy.net/5050/charlotte-isaksson/genderforce-why-didnt-we-dothis-before>, accessed 15 February 2016

Joachim, Jutta and Andrea Schneiker (2012) 'Changing discourses, changing practices? Gender mainstreaming and security', Comparative European Politics, 10:5, 528-563

Kantola, Johanna (2006) Feminists theorize the state (Houndmills, United Kingdom: Palgrave Macmillan)

Kantola, Johanna and Judith Squires (2012) 'From state feminism to market feminism?', International Political Science Review, 33:4, 382-400

Keck, Margaret E and Kathryn Sikkink (1998) Activists beyond borders: advocacy networks in international politics (Cambridge, United Kingdom: Cambridge University Press)

Koops, Joachim A (2012) 'NATO's influence on the evolution of the European Union as a security actor' in Oriol Costa and Knud E Jørgensen (eds) The influence of international institutions on the EU: when multilateralism hits Brussels (Houndmills, United Kingdom: Palgrave Macmillan), 155-185

Kronsell, Annica (2005) 'Gender, power and European integration theory', Journal of European Public Policy, 12:6, 1022-1044

Lombardo, Emanuela (2003) 'EU gender policy: trapped in the "Wollstonecraft dilemma”?', 
The European Journal of Women's Studies, 10:2, 159-180

Lombardo, Emanuela and Petra Meier (2006) 'Gender mainstreaming in the EU: incorporating a feminist reading?', European Journal of Women's Studies, 13:2, 151-166

Lowndes, Vivien and Chris Skelcher (1998) 'The dynamics of multi-organizational partnerships: an analysis of changing modes of governance', Public Administration, 76:2, $313-333$

Mackay, Fiona (2009) "Nested newness" and the gendered limits of change: institutionalising "new politics" in post-devolution Britain', Paper presented at the annual meeting of the Midwest Political Science Association 67th Annual National Conference, Chicago, 2-5 April 2009

Mackay, Fiona, Meryl Kenny and Louise Chappell (2010) 'New institutionalism through a gender lens: towards a feminist institutionalism?', International Political Science Review, $31: 5,573-588$

Mazey, Sonia (2000) 'Introduction: integrating gender - intellectual and "real world" mainstreaming', Journal of European Public Policy, 7:3, 333-345

Meier, Petra and Karen Celis (2011) 'Sowing the seeds of its own failure: implementing the concept of gender mainstreaming', Social Politics, 18:4, 469-489

Mergaert, Lut and Emanuela Lombardo (2014) 'Resistance to implementing gender mainstreaming in EU research policy', European Integration online Papers (EIoP), S1:18:Art.5

Paantjens, Marjolein (2005) 'An institutional perspective on gender mainstreaming', sophia colloquium, 334-347, <http://www.sophia.be/app/webroot/files/Acten\%202005\%20$\% 20 \mathrm{An} \% 20$ institutionalist\%20perspective\%20on\%20Gender\%20Mainstreaming\%20\%20Marjolein\%20Paantjens.pdf>, accessed 8 November 2016

Pierson, Paul (2004) Politics in time: history, institutions and social analysis (Princeton, New Jersey: Princeton University Press)

Pollack, Mark A and Emilie Hafner-Burton, E. (2000) 'Mainstreaming gender in the European Union', Journal of European Public Policy, 7:3, 432-456

Puechguirbal, Nadine (2010) 'Discourses on gender, patriarchy and Resolution 1325: a textual analysis of UN documents', International Peacekeeping, 17:2, 172-187

Rees, Teresa L (1995) Women and the EC training programmes: tinkering, tailoring and transforming (Bristol, United Kingdom: School for Advanced Urban Studies)

Rees, Teresa L (2005) 'Reflections on the uneven development of gender mainstreaming in Europe', International Feminist Journal of Politics, 7:4, 555-574 
Scott, W Richard and Gerald F Davis (2007) Organizations and organizing: rational, natural, and open system perspectives (Upper Saddle River, New Jersey: Pearson Education)

Sherriff, Andrew and Karen Barnes (2008) 'Enhancing the EU response to woman and armed conflict: with particular reference to development policy: study for the Slovenian EU Presidency', Discussion Paper No. 84, Brussels: European Centre for Development Policy Management, <http://www.europarl.europa.eu/document/activities/cont/200805/20080507ATT28495/20 080507ATT28495EN.pdf>, accessed 15 February 2016

Stratigaki, Maria (2005) 'Gender mainstreaming vs positive action: an ongoing conflict in EU gender equality policy', European Journal of Women's Studies, 12:2, 165-186

Supreme Headquarters Allied Powers Europe (2016) SHAPE says farewell to ACO Gender Advisor Ms Charlotte Isaksson this week <https://socialfeed.info/shape-says-farewell-toaco-gender-advisor-ms-charlotte-isaksson-this-week-3744586>, accessed 6 December 2016

SWEDINT (2015) SWEDINT: Swedish Armed Forces International Centre \& Nordic Centre for Gender in Military Operations: course catalogue 2015, <http://www.forsvarsmakten.se/siteassets/english/swedint/engelska/swedint/coursecatalogue-2015.pdf >, accessed 15 February 2016

Swedish Armed Forces (2016) Nordic Battlegroup, $<$ http://www.forsvarsmakten.se/en/about/our-mission-in-sweden-and-abroad/internationalactivities-and-operations/nordic-battle-group>, accessed 15 February 2016

Swedish Government (2006) 'The Swedish Government's action plan to implement Security Council resolution 1325 (2000) on women, peace and security', $<$ http://www.un.org/womenwatch/ianwge/taskforces/wps/nap/Swedish_Action_Plan_final _version.pdf>, accessed 15 February 2016

UNIFEM (2008a) 'Report on ESDP missions in the Democratic Republic of the Congo (DRC): final report', New York: United Nations Development Fund for Women, 10 October 2008

<http://www.isis-europe.eu/sites/default/files/programmesdownloads/2009_artrel_242_esdp\%26drc-gender-report.pdf (expired)

UNIFEM (2008b) 'From commitment to action: the EU delivering to women in conflict and post-conflict: implementing SCR 1325 and 1820 in EU missions: improving immediate and long-term security for women: conference report', <https://www.consilium.europa.eu/uedocs/cmsUpload/27_FR_Pres_UNIFEM_Conf_Repo 
rt_Oct_10_EN_FINAL.pdf >, accessed 15 February 2016

UNSC (2000) 'Resolution 1325 (2000): adopted by the Security Council at its 4213th meeting, on 31 October 2000', SRES document S/RES/1325 (2000), 31 October 2000, New York: United Nations Security Council,

<http://www.peacewomen.org/assets/file/BasicWPSDocs/res1325.pdf>, accessed 15 February 2016

UNSC (2008) 'Resolution 1820 (2008): adopted by the Security Council at its 5916th meeting, on 19 June 2008', SRES document S/RES/1820 (2008), 19 June 2008, New York: United Nations Security Council,

<http://www.peacewomen.org/assets/file/BasicWPSDocs/scr1820english.pdf>, accessed 15 February 2016

UNSC (2009a) 'Resolution 1888 (2009): adopted by the Security Council at its 6195th meeting, on 30 September 2009', SRES document S/RES/1888(2009), 30 September 2009, New York: United Nations Security Council,

<http://www.peacewomen.org/assets/file/BasicWPSDocs/scr1888.pdf>, accessed 15 February 2016

UNSC (2009b) 'Resolution 1889 (2009): Adopted by the Security Council at its 6196th meeting, on 5 October 2009', SRES document S/RES/1889(2009), 5 October 2009, New York: United Nations Security Council,

<http://www.womenpeacesecurity.org/media/pdf-scr1889.pdf>, accessed 15 February 2016

Verloo, Mieke (2001) Another Velvet Revolution: gender mainstreaming and the politics of implementation, IWM Working Paper No. 5/2001, Institute for Human Sciences, Vienna, Austria

Walby, Sylvia (2005) 'Gender mainstreaming: productive tensions in theory and practice', Social Politics: International Studies in Gender, State \& Society, 12:3, 321-343

Weiner, Elaine and Heather MacRae (2014) 'The persistent invisibility of gender in EU policy: introduction', European Integration online Papers (EIoP), 18:Art. 3

Willett, Susan (2010) 'Introduction: Security Council Resolution 1325: assessing the impact on women, peace and security', International Peacekeeping, 17:2, 142-158 